The mobile library and staff preparedness: Exploring staff competencies using the Unified Theory of Acceptance and Use of Technology model

\title{
Sarah-Jane Saravani
}

Waikato Institute of Technology

\author{
Gaby Haddow \\ Curtin University
}




\section{The study}

An investigation into the current state of preparedness of vocational education training (VET) libraries across Australia and New Zealand to develop confident and capable staff engaged in the delivery of mobile services. Specifically focusing on -

1. The skills, knowledge and competencies and specific onthe-job training required by library staff to develop and deliver mobile technology services in the VET sector

2. Employing a slightly-modified version of the Unified Theory of Acceptance and Use of Technology (UTAUT) model as a predictor of behavioural intention and use behaviour 


\section{Identifying staff needs}

Two-pronged approach -

- what competencies are required by library staff

- what training is required to acquire competencies for effective delivery to mobile devices 


\section{Study participants}

New Zealand - 8 ITP libraries

Australia - 6 TAFE libraries

Total of 42 participants - position of Library Manager (16), Systems Librarian (or equivalent) (13) and Librarian (13) 


\section{5 top competencies required by library staff}

1. Competence in using different mobile devices

2. Willingness to try things out

3. Knowledge of devices students are using

4. Skills to enable library resources/services to be accessible on mobile devices

5. Ability to link new technologies with new opportunities 


\section{Top Training Requirements}

1. Hands-on working with a range of mobile devices

2. Using an e-book reader

3. Creating mobile-friendly web pages

4. Applications for iPhones, mobile devices

5. No current training or plans to introduce 


\section{Unified Theory of Acceptance and Use of Technology model (UTAUT)}

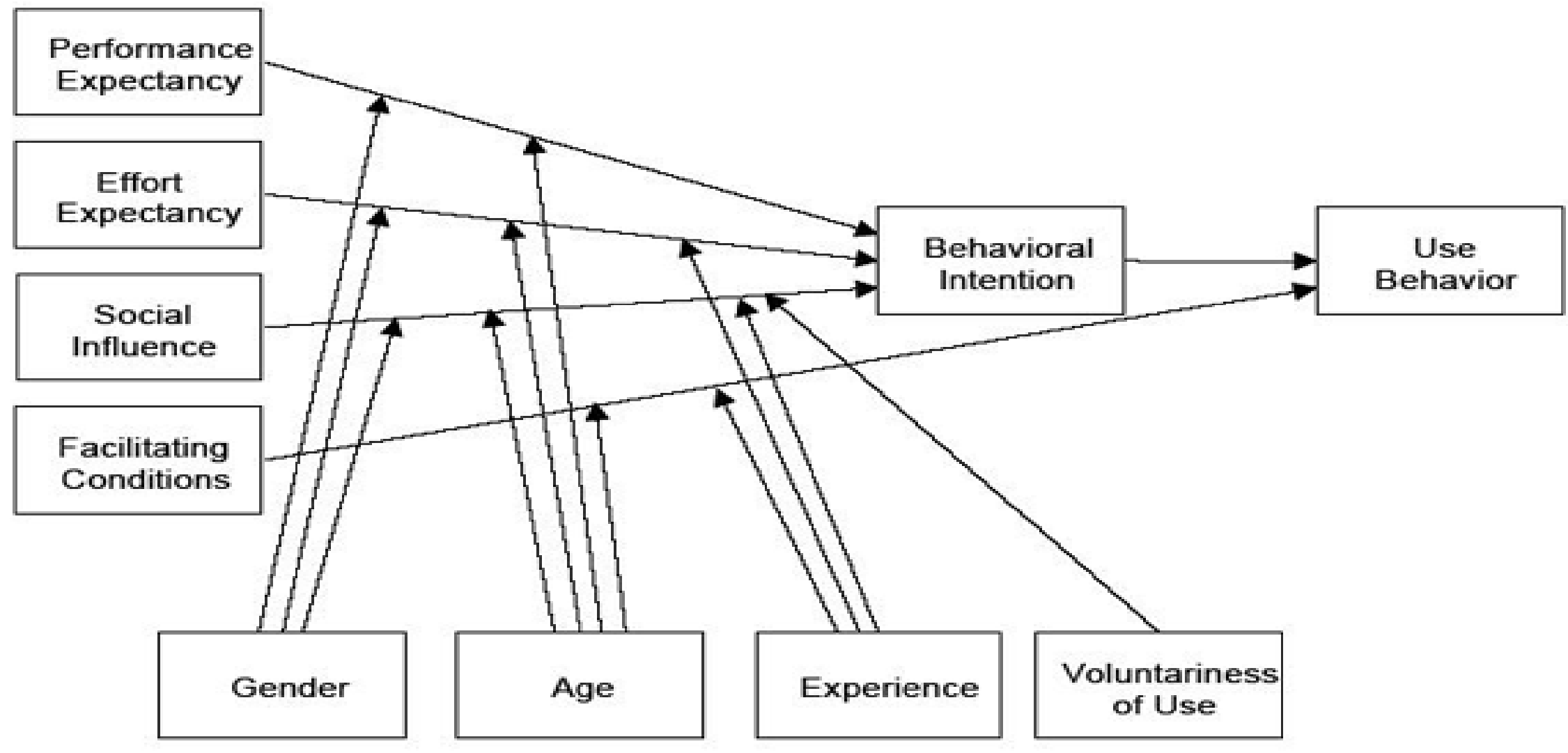

Permission to use for educational purpose received from V. Venkatesh, copyright owner, 3 May 2011.

Venkatesh, V., Morris, M.G., Davis, F.D., and Davis, G.B. “User Acceptance of Information Technology: Toward a Unified View," MIS Quarterly, 27, 2003, 425-478. 


\section{Initial assessment of themes against the UTAUT constructs}

\begin{tabular}{|c|c|c|}
\hline UTAUT construct & Theme & Analysis \\
\hline \multirow[t]{2}{*}{$\begin{array}{l}\text { Performance } \\
\text { expectancy }\end{array}$} & $\begin{array}{l}\text { Hands-on working with } \\
\text { range of mobile devices } \\
(n=13)\end{array}$ & $\begin{array}{l}\text { This response supports the highest } \\
\text { ranked item for Question } 1 \text { and } \\
\text { demonstrates the importance survey } \\
\text { participants placed upon having } \\
\text { physical access to the technologies they } \\
\text { believed they required competency in }\end{array}$ \\
\hline & $\begin{array}{l}\text { Applications for } \\
\text { iPhones, mobile devices } \\
(n=8)\end{array}$ & $\begin{array}{l}\text { There was an awareness amongst } \\
\text { participants of the availability of various } \\
\text { applications for use of mobile devices, } \\
\text { greatest interest was in those library- } \\
\text { related applications that could augment } \\
\text { existing services }\end{array}$ \\
\hline
\end{tabular}




\begin{tabular}{|c|c|c|}
\hline UTAUT model & Theme & Analysis \\
\hline Effort expectancy & $\begin{array}{l}\text { Using an e-book reader } \\
(n=9)\end{array}$ & $\begin{array}{l}\text { A number of participating } \\
\text { libraries were either } \\
\text { including e-book readers in } \\
\text { their range of resources or } \\
\text { intending to. While some } \\
\text { believed use of this } \\
\text { particular device should be } \\
\text { intuitive, others identified } \\
\text { a specific training need }\end{array}$ \\
\hline
\end{tabular}




\begin{tabular}{|c|c|c|}
\hline UTAUT model & Theme & Analysis \\
\hline Social influence & $\begin{array}{l}\text { Creating mobile-friendly } \\
\text { web pages }(n=8)\end{array}$ & $\begin{array}{l}\text { There was an expectation } \\
\text { and a focus on providing } \\
\text { access to library resources } \\
\text { to a range of devices. In } \\
\text { some cases, the } \\
\text { involvement of other areas } \\
\text { in this process, such as the } \\
\text { IT department, was } \\
\text { mentioned as a factor, } \\
\text { usually in the sense of a } \\
\text { barrier to implementation }\end{array}$ \\
\hline
\end{tabular}




\begin{tabular}{|c|c|c|}
\hline UTAUT model & Theme & Analysis \\
\hline Facilitating conditions & $\begin{array}{l}\text { No current training or } \\
\text { plans to introduce }(n=6\end{array}$ & $\begin{array}{l}\text { Reasons varied for this } \\
\text { response, in some cases } \\
\text { there were no appropriate } \\
\text { staff to deliver training, in } \\
\text { other cases there were no } \\
\text { plans for the introduction } \\
\text { of mobile delivery }\end{array}$ \\
\hline
\end{tabular}


Performance expectancy

D1: Creating mobile-friendly web pages

L1: Developing mobile-friendly web pages

Effort expectancy

A1: An understanding of the different ways our resources can be accessed including mobile friendly web pages

E1: Training on creating mobile-friendly web pages would be the one that we need

Social influence

D3: Web pages - software that is used for creating mobile friendly pages will need to be shown and explored by staff

E1: However, I wouldn't expect Library staff to need to know how to develop web applications for mobile devices

Facilitating conditions

B3:The mobile site has been started but hasn't been taken too much further because of other priorities

C1: Also it is a matter at the moment to convince the IT department to get the web page mobile-friendly, this is a priority - last year they didn't manage to get their Web Master to think the time was right 


\section{Testing the data against the UTAUT}

\section{On-the-job Training required}

Analysis at the construct level allows the value of the UTAUT model to emerge -

- strong link between skills in enabling services to be accessible on mobile devices and linking new technologies with new opportunities, and the ability to create mobile-friendly web resources

- Position within the library structure which forms part of Venkatesh's key moderator "Experience" influences three of the four constructs leading to Behavioural Intention and Use Behaviour 


\section{Conclusions \\ Applicability of model}

Initial assessment of the usefulness of the four constructs of the UTAUT model in determining potential outcomes of adoption revealed

In relation to training on development of a specific competency, Position, as a modification of the relationship moderators Age/Experience, had influence on all four constructs and influenced both the degree to which participants

- believed specific training would assist gains in job performance

- acknowledged such training was necessary and increased understanding

- $\quad$ perceived important others believed he/she should use the new system or, in this study, a new mode of technology delivery

- believed organisational and technical infrastructure existed to support use of the system/mode of technological delivery.

Further analysis is planned, the UTAUT model has the potential to predict both skills requirements and successful training implementation 